\title{
Participatory Approach in Designing Tunas Bangsa 02 PAUD School Learning Facilities
}

\author{
*Tutut Nani Prihatmi1, Ghoustanjiwani Adiputra'2, Hani Zulfia Zahro ${ }^{3}$ \\ 1,2,3 Institut Teknologi Nasional Malang, Malang, Indonesia \\ *Email: tutut.nani@lecturer.itn.ac.id (Corresponding Author)
}

\begin{tabular}{ll}
\hline Informasi Artikel & \multicolumn{1}{c}{ DOI: https:/ / doi.org/10.53621/jider.v2i1.72 } \\
\hline Article History: & ABSTRACT \\
Received: November 15, 2021 &
\end{tabular}

\section{INTRODUCTION}

Early childhood education in Indonesia plays an important role in this era of globalization as an effort to build the character of children who have good morality and noble character, are creative, innovative, and competitive (Primayana, 2019). Consequently, early childhood education can act as one of the main factors in increasing the standard of living in the Harjokuncaran Village, Southern Malang Regency.

One of the supporting factors for the development of early childhood education schools (PAUD) in the Harjokuncaran Village is the increasing awareness of the people about the importance of early childhood education (Zahro' et al., 2021), so they do not mind leaving their children in PAUD schools or kindergarten by paying a monthly fee. This potential is also supported by the government's incessant promotion of early childhood education through the education office by providing training for managers and teachers at PAUD institutions, so that PAUD institutions are expected to provide optimal services. By the end of 2020, Harjokuncancaran village which has 11,200 population, established four kindergartens and two PAUD schools. However, the expansion of these PAUD schools in Harjokuncaran Village should be supported by the availability of easily accessible PAUD units, the availability of competent educators, appropriate learning facilities, community participation in improving the quality of education, as well as the government support (Suci et al., 2017).

In the educational process, one of the important components in supporting optimal education to achieve the educational goals is the school facilities and infrastructure (Hasanah, 2020), namely tools or complements used in every educational process. These school facilities may include, classrooms, the principle's room, teacher's rooms, administrative rooms, library rooms, laboratory rooms, workshop rooms, production unit rooms, canteen, power and service installations, places to exercise, praying room, and other spaces needed to support an orderly and continuous learning process. The management of the school's facilities and infrastructure aim to increase the 
effectiveness of optimal teaching and learning activities so that better education quality can be implemented (Kurniawan, 2017) and its proper management will help produce good student outputs in accordance with the educational objectives (Prastyawan, 2016).

Nevertheless, the facts on the field show that there are still many school administrators who do not understand the infrastructure required by an early childhood education institution that is suitable for the needs of children and does not know how to manage it (Direktorat Pembinaan Pendidikan Anak Usia Dini, 2014). Even though the standard of infrastructure and school facilies has been set, Tunas Bangsa 02 PAUD school is still not able to complete it properly. As this school is a private school that manages its own finances and does not take any school fee (free tuition), the improvements to infrastructure and teaching resources have been carried out independently by the school's foundations, donations, and some assistance from the local government. Due to limited funds, it is necessary to have proper and directed planning so that the development of this learning facility is in accordance with the most important needs. To determine these priorities, it is necessary to make joint decisions and cooperation with all relevant components of the community.

This study therefore aims at proposing a partisipatory approach to help Tunas Bangsa 02 PAUD school mapping out the most priority facility needs and plan the overall school design according to architectural principles. Budiyanto (2011) stated that participatory planning directly involves involve all relevant parties in the decision-making and implementation process. Andriany (2015) stated that the participatory approach model is very feasible to help improve the living standards of the underprivileged and the small business community in Medan City. While in designing public facilities, Ujianto (2019) claimed that participatory approach has provided satisfactory results, since it was carried out to empower potential local people in collaboration with particular experts to maintain the community's character of mutual cooperation.

Table 1. Participation Rate in Mitchel (1997)

\begin{tabular}{lll}
\hline Participatory Stages & The Nature of Participation & Level of Power Distribution \\
\hline $\begin{array}{l}\text { 1. Manipulation } \\
\text { 2. Therapy }\end{array}$ & $\begin{array}{l}\text { stamped committee } \\
\text { the power holders educate the } \\
\text { public } \\
\text { community rights and choices } \\
\text { are identified } \\
\text { the community is heard, but } \\
\text { the advice is not always used } \\
\text { community suggestions are }\end{array}$ & \\
4. Consultation & $\begin{array}{l}\text { accepted but not always } \\
\text { implemented }\end{array}$ & \\
5. Placation & $\begin{array}{l}\text { reciprocity negotiated } \\
\text { the community is given power } \\
\text { for part or all of the program }\end{array}$ & \\
6. Partnership & &
\end{tabular}

This initial research will focus on the methodology and introduction of a participatory approach model for planning the learning facilities, which is based on the design process in observation (Anrstein, 1969) referred to by Mitchell et al. (1997), that a participatory approach can show how shared policies are distributed from managers to communities. On this basis, Arnstein argues that various levels of involvement can be identified, from non-participation to joint policymaking, both from local authorities to the number of participants in the program. Eventually, it is hoped that the use of this participatory approach will be able to provide appropriate and targeted planning solutions for the managers of Tunas Bangsa 02 PAUD school and can serve an example of a planning model for other early childhood education (PAUD) schools. 


\section{METHOD}

In this study, researchers describe the design of participatory mentoring to map learning facilities. The participatory research approach is intended as a shared process to generate knowledge that leads to new insights for the community and researchers themselves (Bergold, 2012), in which the objectives of the inquiry and research questions develop from the perspective of science and practice. This participatory study was conducted directly with the individuals who had been impacted (Bergold, 2012). Therefore, the participants in this program were the owner of the foundation, financial donors, representatives of parents, and all teachers, accompanied by a team of experts. The program was done from June to October 2021. The location of the program is Tunas Bangsa 02 PAUD school in the Harjokuncaran village, Southern Malang Regency. Data collection in this study used observation, interviews, and secondary data from related journals. Referring to Miles, et al. (2014), data analysis in this descriptive research contains three sub-processes, namely data reduction, data display, and conclusions drawing/verification.

\section{RESULT and DISCUSSION Result}

In this study, all participants are involved as knowing subjects who will bring their perspective of thinking into the process of discussion and decision-making processes. Based on the results of interviews, two main conclusions have been drawn.

1. Human Resources Potential

The results of the initial interview indicated that $100 \%$ of the interviewees understood the program's objectives and were ready to help physically and mentally with the traditional principle of "gotong royong". During the meetings, the participants contributed actively to the field survey and the exploration of the school's development ideas. This participatory process was ultimately able to encourage the community to actively participate in the development process of Tunas Bangsa 02 PAUD school in particular and Harjokuncaran Village in general, as suggested by Cornwall (1995).

2. Participatory Levels and Processes

Combined with the result of the field observation and discussion, the team arrange the design of the participatory approach used in this study during the first year and planned to be implemented in the following years, according to Anrstein's model (1969) in Mitchell et al. (1997) as seen in Figure 1.

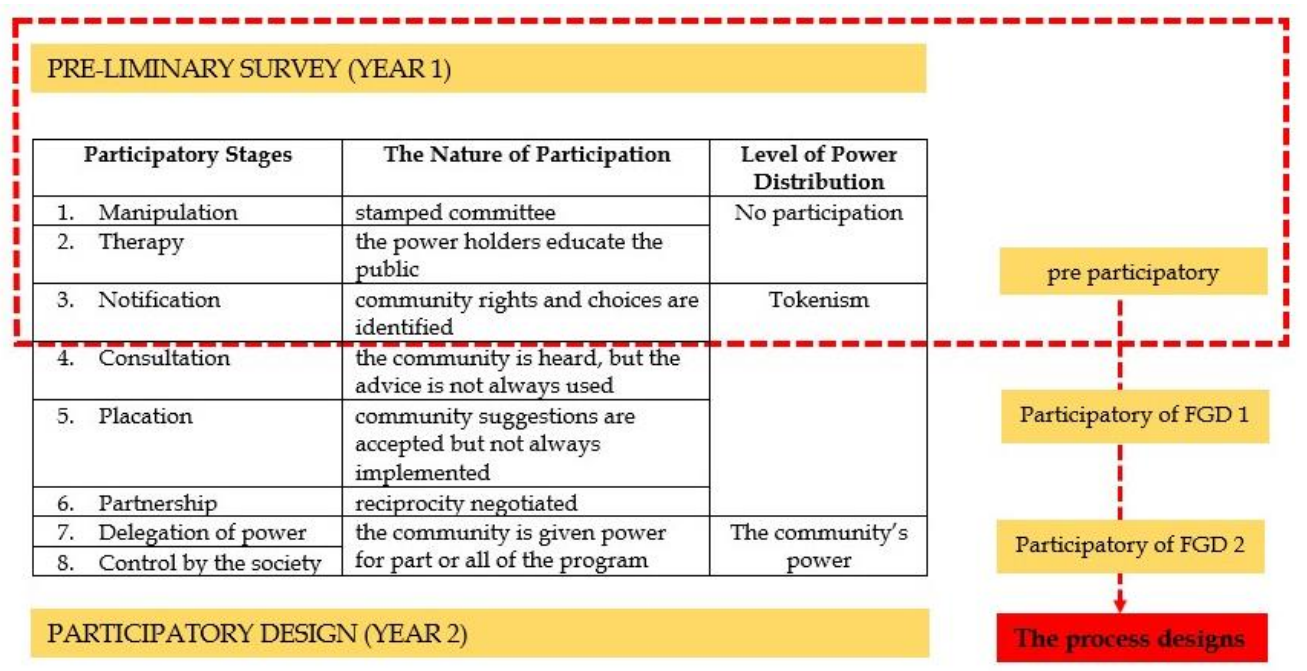

Figure 1. the process design of participatory approach implementation 


\section{Discussion \\ Participatory Stage of "Manipulative and Therapy Process"}

The manipulative process is a participatory stage involving researchers and policy makers, namely: researchers, PAUD Tunas Bangsa, PAUD Foundation. It is called a manipulative participation process because of the manipulation process due to the direct non-involvement between the object of service and the researcher. In this process the involvement of the stamped committee is stakeholders and researchers.

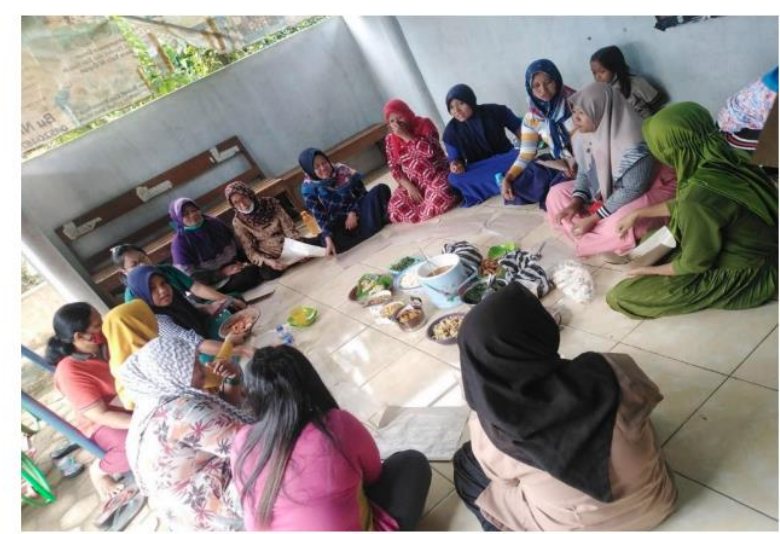

Figure 2. Initial discussion of the teachers, representatives of parents, foundations, and donors as the manipulative and theraphy process

\section{Participatory Stage of "Notification Process"}

The participatory method at this stage is used to maintain the cooperative character of the community and identify priority needs. This participatory approach is carried out during the study process, making design concepts, selecting designs, and alternative designs. Activities that was carried out for problem solving including the Notification study. This process was done by conducting a joint study with a participatory approach in the form of a Forum Group Discussion (FGD). The FGD method is one of the strategies for collecting data involving social interactions among individuals in a series of discussions (Afiyanti, 2008). This participatory study was conducted directly with the affected individuals with the aim of rebuilding their knowledge and talents as part of the understanding and empowerment process. Participants in this study were: 1.) Head of Tunas Bangsa Foundation, 2.) Head of PAUD Tunas Bangsa 02, 3.) PAUD Tunas Bangsa 02 teacher, 4.) Donors, and 5.) Representatives of students' guardians. This joint study will discuss the existing learning facilities and those that will be improved on a priority scale. At this stage, the following activities are carried out:

a. Planning review to gather information on policies and school development plans.

b. Preparation of the Tunas Bangsa PAUD Area Base Map 02.

c. Resource mapping and self-help.

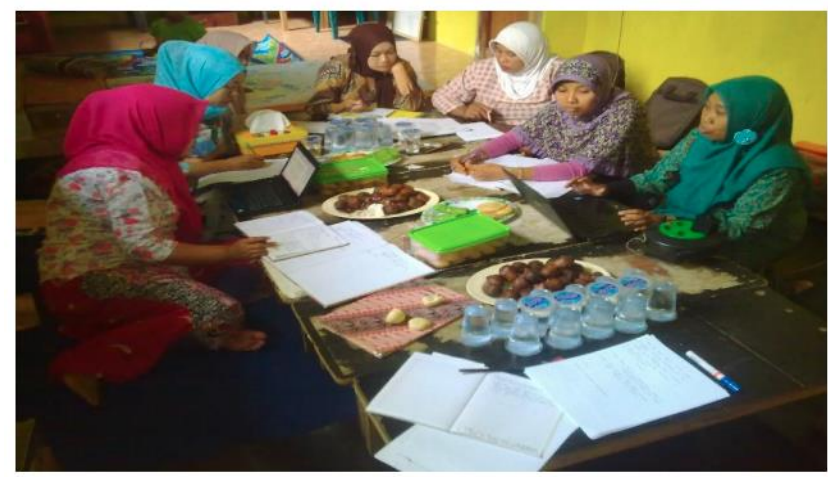

Figure 3. Process of identifying needs 


\section{Participatory Stage of "Consultation Process"}

This stage is the coaching/assistance and consultation in determining the concept of designing learning facilities and making possible alternative designs for the design of facilities and infrastructure that will be applied. After the above processes has been carried out, the next step is to design a learning facility based on the results of discussion and mutual agreement.

This stage was attended by the foundation builder, the head of early childhood education, 2 teachers, representatives of the students' parents, and permanent donors who worked with the proposing team and students from the college proposing team. Activities carried out at this stage are:
a. Making an agreement on the determination of Priority Areas
b. Conducting Area development analysis
c. Agree on the plan for the arrangement of the building and the environment
d. Preparation of detailed sub-project plans
e. Public consultation process

\section{CONCLUSION}

Participatory approach was used as an effort to optimally design learning facilities at Tunas Bangsa 02 PAUD school with the basic principle of "gotong royong". Of the eight participatory design processes that have been implemented in this initial study, the researchers found a participatory method that is suitable to be implemented in the next year's implementation, that is the program design in the consultation process, including 5 stages, those are: First, make an agreement on the determination of Priority Areas. Second, analysis of area development in macro and micro. The third stage is panning agreement for the arrangement of the building and the environment according to the potential analysis. Next stage is the preparation of detailed sub-project plans on objects in accordance with the agreement. Finally, the last stage is the process of public consultation and participatory public design.

\section{REFERENCES}

Afiyanti, Yani. (2008). Focus Group Discussion (Diskusi Kelompok Terfokus) Sebagai Metode Pengumpulan Data Penelitian Kualitatif, Jurnal Keperawatan Indonesia, Volume 12, No. 1, hal 58-62.

Andriany, Dewi. (2015). Pengembangan Model Pendekatan Partisipatif Dalam Memberdayakan Masyarakat Miskin Kota Medan untuk Memperbaiki Taraf Hidup. Seminar Nasional Ekonomi Manajemen Dan Akuntansi (Snema), 30-39

Bergold, Jarg \& Thomas, Stefan. (2012). Participatory Research Methods: A Methodological Approach in Motion. Historical Social Research / Historische Sozialforschung. 37. 191-222. $10.2307 / 41756482$.

Budiyanto, H. (2011). Pendampingan dalam Proses Perencanaan Partisipatif ProgramPenataan Lingkungan Permukiman Berbasis Komunitas (PLPBK), LOCALWISDOM-JURNAL ILMIAH ONLINE, III (1), 34-40, https:/ / doi.org/10.26905/lw.v3i1.1386

Cornwall A, Jewkes R. 1995. What is participatory research? Social Science E Medicine, 41(12),1667-1676, https: / / doi.org/10.1016/0277-9536(95)00127-S

Eric Asaba \& Yolanda Suarez-Balcazar (2018) Participatory research: A promising approach to promote meaningful engagement, Scandinavian Journal of Occupational Therapy, 25:5, 309-312, https:/ / doi.org/10.1080/11038128.2018.1541224 
Direktorat Pembinaan Pendidikan Anak Usia Dini. (2014). Pedoman Prasarana Pendidikan Anak Usia Dini.

Hasanah, R. (2020). Pengaruh Manajemen Sarana dan Prasarana terhadap Kegiatan Belajar Mengajar di TK Al-Fadlillah Maguwoharjo Yogyakarta. Golden Age Jurnal Ilmiah Tumbuh Kembang Anak usia Dini, 5(3), 115-122, https://doi.org/10.14421/iga.2020.5303

Kurniawan, N. (2018). Pengaruh Standart Sarana dan Prasarana Terhadap Efektifitas Pembelajaran di TK Al-Firdaus. Jurnal Warna: Pendidikan Dan Pembelajaran Anak Usia Dini, 2(2), 14-26, https:/ / doi.org/10.24903/jw.v2i2.191

Miles, M.B, et.al. (2014). Qualitative Data Analysis. London: Sage Publication.

Mitchell, R. K., Agle, B. R., \& Wood, D. J. (1997). Toward a theory of stakeholder identification and salience: Defining the principle of who and what really counts. Academy of Management Review, 22(4), 853-886. https:/ / doi.org/10.2307/259247

Prastyawan. (2016). Manajemen Sarana dan Prasarana Pendidikan. Al Hikmah: Jurnal Studi Keislaman, 6(1), 33-46, https:/ / doi.org/10.36835/hjsk.v6i1.2797

Primayana, K.H. (2019). Perencanaan Pembelajaran Pendidikan Anak Usia Dini Dalam Menghadapi Tantangan Revolusi Industri 4.0. Prosiding Seminar Nasional Dharma Acarya ke-1, 321-328.

Suci, R. P., Suhermin, S., \& Triyonowati, T. (2017). Peningkatan Kualitas Pendidikan Anak Usia Dini Melalui Penyediaan Sarana Penunjang Proses Pembelajaran Pada Pos Paud di Kelurahan Merjosari Malang. Jurnal Inspirasi Pendidikan, 7(1), 52-65, https://doi.org/10.21067/jip.v7i1.1555

Ujianto, B.T \& T.N, Prihatmi. (2019). Kegiatan Pendampingan Perancangan Fasilitas Umum Kompleks Kavling Sidomakmur Baru, Desa Mulyoagung, Kecamatan Dau Kabupaten Malang. PAWON: Jurnal Arsitektur, III(02) 1-13, https://doi.org/10.36040/pawon.v3i02.862

Zahro', H. Z., Prihatmi, T. N., \& Putra, G. A. (2021). A Preliminary Survey in Improving Learning Space Facilities and Environment in "Tunas Bangsa\&quot; Early Childhood Education. ESE International Journal (Environmental Science and Engineering), 4(1), 28-33 